\title{
Analisis Kefasihan Pembelajar Bahasa Korea dalam Membaca Teks Berbahasa Korea
}

\author{
Theresia Avila Rencidiptya Gitanati Firstantin \\ Universitas Gadjah Mada \\ rencidiptya@ugm.ac.id
}

\begin{abstract}
Fluency in reading is one of the important factors in language learning, especially foreign languages. Fluency in reading can be seen from understanding vocabulary, reading speed, rhythm and expression, also understanding the reading's contents. Reading fluently is one of the effective learning methods to help for understanding the vocabulary and the content of the text. Reading fluency is needed by Korean leaners when working with Korean stakeholders. This study analyzes the fluency of Korean language learners in reading Korean texts using qualitative descriptive methods. This studyfound that the learning period and the Korean Language Proficiency Test score of the learner are not always directly assessed to learner's fluency in reading. Fluency in reading is also influenced by some factors, such as how much intensity and frequency of learners learn new vocabulary through text, and how instructors provide learning about morphology in how to read a word in Korean.
\end{abstract}

Keywords fluency analysis, leaners of Korean language, Korean language morphology, fluency reading, reading strategies

\section{Intisari}

Kefasihan dalam membaca merupakan salah satu faktor penting dalam pembelajaran bahasa khususnya bahasa asing. Kefasihan dalam membaca dapat terlihat dari pemahaman kosakata, kecepatan membaca, keselarasan ritme dan ekspresi, dan pemahaman isi bacaan. Membaca secara fasih merupakan salah satu cara pembelajaran yang efektif untuk membantu pemahaman kosakata dan isi bacaan. Kefasihan membaca sangatlah diperlukan oleh pembelajar bahasa Korea ketika berada di dunia kerja terutama berhadapan langsung dengan pemangku kepentingan dari Korea. Penelitian ini menganalisis kefasihan pembelajar bahasa Korea dalam membaca teks berbahasa Korea dengan menggunakan metode deskriptif kualitatif. Melalui penelitian ini dapat ditemukan bahwa periode pembelajaran dan nilai TOPIK pembelajar tidak selalu berbanding lurus dengan kefasihan dalam membaca. Kefasihan dalam membaca juga dipengaruhi seberapa banyak intensitas dan frekuensi pembelajar dalam mempelajari kosakata baru melalui teks, serta bagaimana pengajar memberikan pembelajaran mengenai morfologi cara membaca suatu kata dalam bahasa Korea.

Kata kunci analisis kefasihan, pembelajar bahasa Korea, morfologi bahasa Korea, faktor kelancaran membaca, strategi membaca 
Pendahuluan

Keberhasilan pembelajar dalam mempelajari suatu bahasa, terutama bahasa asing, dapat dinilai melalui berbagai macam cara. Seorang pembelajar bahasa asing dikatakan berhasil tentunya adalah ketika dapat berkomunikasi dengan penutur asli bahasa tersebut tanpa mengalami kesulitan. Keberhasilan pembelajar bahasa asing juga dapat terlihat dari kefasihan pembelajar dalam berkomunikasi, tidak terbata-bata dan menggunakan kosakata dan tata bahasa yang tepat sesuai dengan konteks pembicaraan. Menurut Blachowicz \& Wogman Shadow (1995), kefasihan membaca adalah kemampuan membaca teks, baik teks yang mudah sampai dengan teks yang sulit, dengan menggunakan intonasi dan tingkat kecepatan yang tepat. Sehingga dalam membaca teks, tidak terlalu lambat dan juga tidak terlalu cepat, juga menggunakan intonasi yang jelas sehingga dapat dimengerti. La Berge \& Samuels (1974) juga menambahkan bahwa seorang pembaca yang membaca suatu teks secara fasih akan lebih banyak menggunakan

kecerdasan

intelektualnya untuk memahami kosakata dan secara otomatis akan lebih mudah mengerti isi keseluruhan bacaan. Sebaliknya, seorang pembaca yang kurang fasih dalam membaca teks, hanya akan menghabiskan waktunya untuk memahami arti kata per kata, sehingga mengalami kesulitan dalam memahami dan mengerti keseluruhan isi bacaan. Oleh karena itu, kefasihan dalam membaca merupakan salah satu mediasi penting yang menghubungkan antara pemahaman kosakata dengan kemampuan membaca suatu teks.

Tidak terkecuali dengan pembelajar bahasa Korea. Pembelajar bahasa Korea akan dianggap berhasil ketika dapat berkomunikasi secara fasih tanpa mengalami kendala yang berarti dengan penutur asli. Kefasihan pembelajar dapat terlihat dari cara penyampaian kalimat, penggunaan tata bahasa dan kosakata, bagaimana kemampuan dalam membaca suatu teks dan mendengarkan lawan bicara tanpa ada masalah sedikitpun. Penyampaian kalimat yang keliru, akan membuat maksud dari pembicara 
kepada lawan bicara tidak memberikan pengaruh pada tersampaikan dengan baik atau yang maknanya yang cukup signifikan.

biasa kita kenal dengan kata miskomunikasi. Miskomunikasi terjadi ketika pesan yang disampaikan oleh pembicara tidak tersampaikan dengan baik oleh lawan bicara.

Bahasa Korea merupakan salah satu bahasa yang memiliki kesulitan tersendiri untuk dipelajari. Perbedaan huruf dalam satu suku kata, dapat mengubah makna dalam kata tersebut. Sebagai contoh adalah kata 커피 (kheophi) dan 코피 (khophi). Dari kedua kata tersebut, dapat dilihat perbedaan yang hanya terdapat pada huruf ' $才$ ' (eo) dan '', (o). Namun kedua huruf ini membuat kata tersebut memiliki arti yang jauh berbeda. Pada kata 커피(kheopi) memiliki arti minuman kopi yang sering diminum oleh kebanyakan orang. Sementara itu, kata 코피 (khopi) memiliki arti darah yang keluar dari hidung, atau yang sering dikenal dengan istilah mimisan. Perbedaan kedua kata ini terlihat sangat sederhana, namun ternyata bahasa Korea lebih difokuskan kepada praktek berbicara, menyimak, dan menulis. Dengan metode pembelajaran yang diterapkan pada saat ini, pendidik dan pembelajar lebih terfokus untuk mengembangkan kemampuan berbicara, menyimak, dan menulis. Metode pembelajaran seperti ini mengakibatkan kemampuan pembelajara dalam membaca teks berbahasa Korea semakin berkurang. Hal ini terjadi ketika banyak mahasiswa atau pembelajar bahasa Korea yang kesulitan mengerjakan TOPIK (Test of Proficiency in Korean) pada bagian Reading/Membaca. Waktu yang tidak cukup, isi bacaan yang tidak dapat dimengerti, dan masih banyak faktorfaktor yang membuat pembelajar kesulitan dalam mengerjakan ujian tersebut. Hal ini tidak lain disebabkan oleh masih kurangnya peningkatan kemampuan membaca teks berbahasa Korea dalam pengajaran maupun pembelajaran bahasa Korea. 
Skema dan materi pengajaran bahasa Korea sudah mulai dikembangkan seiring berjalannya waktu. Hal ini dipengarungi oleh naiknya peminat yang ingin mempelajari bahasa Korea. Meningkatnya minat para siswa mempelajari bahasa Korea di berbagai negara sangatlah pesat, tidak hanya di Indonesia saja. Hal ini terlihat dari banyaknya program studi maupun institusi terkait bahasa Korea yang tersebar di berbagai negara, serta banyaknya pelajar asing yang memilih untuk melanjutkan studi di Korea Selatan. Di Indonesia sendiri, perkembangan minat siswa terhadap bahasa Korea dapat terlihat sejak masuknya Hallyu/Korean Wave ke Indonesia. Pada tingkat pendidikan tinggi, program studi bahasa Korea sudah terbentuk di beberapa universitas seperti Universitas Gadjah Mada, Universitas Indonesia, UNAS dan UPI. Di Universitas Gadjah Mada, peningkatan minat mahasiswa terhadap bahasa Korea dapat terlihat melalui meningkatnya jumlah mahasiswa Prodi Korea baik D3 maupun S1 dari tahun ke tahun sejak tahun 2006 sampai dengan saat ini. Peningkatan jumlah mahasiswa Program Studi Bahasa Korea juga diikuti dengan peningkatan kebutuhan perusahaan dan lembaga Korea akan profil lulusan yang berkualitas. Kemampuan lulusan Program Studi Bahasa Korea tidak hanya dinilai dari kemampuan berbicara, mendengar, dan menulis saja, namun juga membaca, yang merupakan salah satu kriteria kemampuan yang harus dimiliki oleh setiap pembelajar bahasa Korea.

Melalui survei yang dilakukan secara acak kepada pembelajar Korea dari beberapa negara, sebagian besar responded menyatakan bahwa di antara bentuk pembelajaran bahasa Korea, praktik berbicara, menyimak dan menulis adalah bagian yang paling sulit dan menganggap bahwa praktik membaca merupakan bagian yang mudah. Namun setelah respondenresponden tersebut diberikan teksteks berbahasa Korea, mulai dari kalimat yang mudah hingga kalimat yang sulit, ternyata respondenresponden tersebut mengalami kesulitan dan banyak melakukan 
kesalahan dalam membaca teks. Dari hasil survei ini dapat disimpulkan bahwa praktik membaca juga memiliki kesulitan yang tidak jauh berbeda, atau dapat dikatakan sama dengan praktik berbicara, menulis dan menyimak. Oleh karena itu, praktik membaca dan aplikasinya juga sangat perlu untuk difokuskan, sehingga setiap aspek keterampilan berbahasa Korea yang dimiliki oleh pembelajar menjadi seimbang. Profil pembelajar juga akan meningkat karena memiliki kecakapan yang lengkap dari segi keterampilan berbicara, mendengar, membaca, maupun menyimak materimateri berbahasa Korea.

\section{Metodologi}

Penelitian ini menggunakan metode deskriptif kualitatif untuk melihat faktor-faktor yang mempengaruhi kefasihan pembelajar dalam mempelajari bahasa Korea. Untuk melihat dan mengetahui tingkat kefasihan pembelajar dan faktorfaktor penghambatnya, dilakukan survei terhadap pembelajar bahasa Korea yang sedang dalam proses belajar bahasa Korea. Metode penelitian dengan menggunakan survei dilakukan untuk menjaga kevalidan dari hasil data tersebut. Distribusi kuesioner dilakukan secara online melalui e-mail, dengan mengambil 10 orang mahasiswa asing yang pernah mempelajari bahasa Korea dalam kurun waktu lebih dari 3 tahun dan yang sudah memiliki nilai TOPIK minimal level menengah (Topik 3 dan 4) sebagai sampel penelitian. Pemilihan mahasiswa asing dengan kemampuan bahasa Korea tingkat menengah adalah terkait dengan kemampuan bahasa Korea dasar yang dimiliki. Dengan memiliki kemampuan dasar bahasa Korea yang baik, serta lamanya waktu pembelajaran, maka kemampuan membaca dan berbahasa Korea dari responden akan lebih mudah terlihat dan mudah untuk diketahui. Seseorang yang sudah mendapatkan nilai TOPIK minimal level menengah dapat dikatakan pembelajar tersebut sudah mengetahui dasar-dasar dalam berkomunikasi menggunakan bahasa Korea. Secara hipotesis, pembelajar yang berada pada titik tersebut, kecil kemungkinannya untuk melakukan 
kesalahan dalam membaca suatu teks. Jika mempertimbangkan kurun waktu pembelajaran, secara hipotesis pula, semakin lama seorang pembelajar mempelajari bahasa Korea, maka akan semakin fasih dalam menggunakan bahasa tersebut. Namun dari beberapa tes yang telah dilakukan terhadap responden dalam membaca suatu bacaan, muncul beberapa kesalahan yang cenderung sama antar satu responden dengan responden yang lain. Melalui sampel jawaban dari responden ini dapat diketahui faktorfaktor apa saja yang dapat mempengaruhi terjadinya kesalahan pembelajar dalam membaca suatu teks yang telah diberikan.

\section{Hasil dan Pembahasan}

Dalam kefasihan membaca yang dimiliki pembelajar, terdapat pula ketepatan pemahaman kosakata, tingkat kecepatan membaca, keselarasan ritme dan ekspresi, dan pemahaman isi bacaan. Membaca secara fasih merupakan salah satu cara pembelajaran yang efektif untuk membantu pemahaman kosakata dan isi bacaan. Pikulski \& Chard (2005) menyatakan bahwa secara struktur, kefasihan dapat terbagi menjadi 4; yaitu ketepatan, kecepatan, kualitas oral reading dan kemampuan memahami isi bacaan.

Untuk menganalisis kemampuan membaca pembelajar bahasa Korea, ada 3 jenis bacaan yang disajikan untuk dibaca oleh responden. Ketiga jenis bacaan terdiri dari kalimat pendek dengan kosakata tingkat menengah, paragraf panjang dengan kosakata tingkat atas, dan paragraf yang di dalamnya terdiri dari beberapa angka berbeda. Pemilihan jenis bacaan didasari pada sasaran responden yang merupakan pembelajar bahasa Korea yang berada pada level menengah dan atas. Sehingga kosakata yang dipilih dalam paragraf adalah kosakata yang muncul pada level menengah dan atas. Sedangkan untuk pemilihan paragraf yang terdapat angka di dalamnya, hal ini dikarenakan dalam bahasa Korea, pembacaan untuk angka dibedakan menjadi 2 jenis yaitu angka Sino Korea dan angka yang diadaptasi dari Hanja. Menurut Barr, Blachowicz \& Wogman Shadow (1995), kefasihan membaca juga dipengaruhi oleh familiar atau 
tidaknya pembaca terhadap bahan bacaan. Semakin familiar pembaca terhadap bahan bacaan, maka ritme dan kecepatan dalam membaca akan meningkat.

Ketiga materi bacaan yang diberikan kepada responden pembaca adalah sebagai berikut.

<Bacaan Pertama> 깻잎을 깨의 잎이라 생각하지 못하는 사람이 많다. 참깨와 들깨는 우리 말 이름은 비슷하지만 분류학적으로 참깨는 꿀풀 목 참깻과이므로 상당히 거리가 있다. ${ }^{1}$

[kkaenip-eul kkae-e iphira saenggakhaji mothaneun saram-i mantha. Chamkkaewa deulkkae-neun urimal ireum-eun biseuthajiman bullyuhakjeokeuro chamkkae-neun kkulphul mok chamkkaetkwaimeuro sangdanghi georiga itta.]

Arti: Banyak orang menganggap bahwa daun perila adalah daun wijen. Meskipun dalam bahasa Korea daun perila dan daun wijen memiliki nama yang sama, namun jika dibedakan secara kategorinya, wijen merupakan rumpun Lamiales yang sangat berbeda jauh dengan perila.

Bacaan pertama merupakan kalimat sederhana yang terdiri dari dua buah kalimat di dalamnya. Bacaan pertama berisi tentang perbedaan antara biji wijen dan biji perila. Kalimat ini dipilih sebagai kalimat pertama karena kalimatnya sederhana dan kecil kemungkinan pembelajar mengalami kesulitan dalam membaca.

<Bacaan Kedua> 일반적으로 채소를 기를 때는 영양공급을 위해 비료를 주는데, 일반 채소의 경우 화학비료를 쓴다. 그러나 일반 채소보다 값비싼 유기농 채소에는 유기비료를 사용한다. 유기비료는 주로 동물의 분뇨를 발효시킨것과 풀을 썩힌 것을 섞어 만든다. 사람들 대부분은 유기농 채소가 일반채소보다 더 안전하다고 생각하지만 유기비료의 원료인 동물 분뇨는 안전성에 문제가 있을 수 있다. 항생제에 노출된 동물의 분뇨에는 항생물질이 존재하는데, 이것이 건강에 좋지 않은 영향을 미치기 때문이다. 또한 분뇨에 많이 들어있는 질소 성분이 고기나 생선에 포함되어

${ }^{1}$ https://namu.wiki/w/\%EA\%Bg\%BB\%EC\%9E\%8E 
있는 단백질과 결합하면 암 발생물질을 생성할 수 있다.

[Ilbanjeokero chaeso-reul gireul ttaeneun yeongyang gogeub-eul wihae biryoreul juneunde, ilban chaeso-e gyeongu hwahak biryoreul seunda. Geurona ilban chaeso-boda gabbissan yuginong chaeso-eneun yugi biryo-reul sayonghanda. Yugi biryo-neun juro dongmure bunnyoreul baryosikhin geotgwa phur-eul sseokhin geoseul seokkeo mandeunda. Saramdeul daebubun-eun yuginong chaesoga ilban chaeso-boda deo anjeonhadago saenggakhajiman yuhi biryo-e wollyoin dongmul bunyeoneun anjeonseong-e munjega isseulsu itta. Hangsaengje-e nochuldwen dongmure bunyo-eneun hangsaeng muljiri jonjaehaneunde, igeosi geon-gange johci aneun yeonghyang-eul michigi ttaemunida. Ttohan, bunyo-e manhi deureo itneun jilso seongbuni gogina saengseon-e pohamdwe-eo ittneun dambaekjilgwa gyeorhabhamyeon am balsaeng muljireul saengseonghal su itta.]

${ }^{2}$ The $23^{\text {rd }}$ of Korean Proficiency Test Advanced Reading section number 49-50
Arti: Pada umumnya, sayuran akan diberi pupuk sebagai nutrisi, dan pada sayuran biasa menggunakan pupuk kimia sebagai nutrisinya. Namun pada sayuran organik yang harganya lebih mahal daripada sayuran biasa akan dipupuki menggunakan pupuk kandang. Pupuk kandang pada umumnya terbuat dari campuran kotoran hewan ternak yang dikeringkan dan dicampur dengan rerumputan. Meskipun sebagian besar orang berpikir bahwa sayuran organik jauh lebih aman daripada sayuran biasa, namun pupuk kandang juga terdapat kekurangan dalam hal keamanan. Zat antibiotik yang keluar dari pupuk hewani memiliki kandungan zat yang tidak baik untuk tubuh. Terlebih lagi, zat nitrogen yang terkandung dalam pupuk kandang juga dapat menimbulkan kanker jika tercampur dengan protein yang terdapat pada daging maupun ikan.

Bacaan kedua merupakan sebuah paragraph yang cukup panjang, yang berisi tentang penggunaan pestisida pada sayuran. Pemilihan bacaan kedua didasari pada jenis kalimat tingkat menengah dengan 
kosakata yang lebih sulit daripada Bacaan pertama. Kata-kata yang terdapat pada bacaan kedua ini bukanlah kata-kata yang sering digunakan dalam bahasa sehari-hari pada umumnya, namun lebih kepada bahasa teknis. Pemilihan bacaan ini digunakan untuk mengetahui bagaimana kefasihan pembaca dalam membaca teks dengan kosakata yang jarang mereka dengar ataupun gunakan sebelumnya.

<Bacaan Ketiga> 청소년은 성년과 어린이의 중간 시기이다. 흔히 ‘청소년’이라 하면 만 13 세 이상만 18 세이하 (세는 나이로 14 세 이상 19 세 이하)사람을 말하며, 통상 중학교와 고등학교의 시기에 해당된다. 청소년에 대한 연령 규정은 법령이나 규정에 따라 다른데, 대한민국의 청소년 기본법에는 만 9 세에서 24 세 사이(이하연령은 전부 '만 나이')의 사람으로 규정되어 있다. 그러나 청소년의 보호와 규제를 목적으로 하는 청소년 보호법에서는 19 세 미만(19 세가 되는 해의 1 월 1 일을 맞이한
사람은 제외한다)을청소년으로 정의하고 있다. ${ }^{3}$

[Cheongsonyeon-eun seongnyeo-gwa eorini-e junggan sigi-ida. Henhi 'cheongsonyeon'ira hamyeon man 13 se isang man 18se iha (se-neun nairo 14se isang 19se iha) sarameul marhamyeo, thongsang junghakkyowa godeunghakkyo-e sigie haedangdwenda. Cheongsonyeon-e daehan yeollyeong gyujeongeun beobryeongina gyujeonge ttara dareunde, Daehanminguke cheongsonyeon gibeobeneun 9seeseo 24 se sai (iha yeollyeongeun jeonbu 'man nai') e sarameuro gyujeongdwe-eo itta. Geureona cheongsonyeon-e bohowa gyujereul mokjeokeuro haneun cheongsonyeon bohobeobeseoneun 19 se miman (19sega dweneun hae-e irol irirul majihan sarameun jewehanda.]

Arti: Remaja adalah fase yang berada di antara dewasa dan anak-anak. Istilah 'remaja' biasanya menunjukan orang yang berusia antara 13 tahun

${ }^{3}$ http://blog. naver. com/PostView. nhn?blogId=b akbht\&logNo=221081968640\&parentCategory $\mathrm{No}_{\mathrm{o}}=\mathrm{\&}$ categoryNo=59\&viewDate $=\&$ isShowPopularPosts $=$ true\&from=search 
sampai 18 tahun (menggunakan tahun Internasional, namun dengan tahun Korea adalah usia 14 sampai 19 tahun). Biasanya usia remaja berkisar antara usia anak SMP sampai dengan SMA. Aturan tentang penentuan usia yang disebut dengan 'Remaja' berbedabeda tergantung pada aturan dan hukum yang berlaku. Berdasar pada aturan dasar mengenai usia di Korea, remaja dikategorikan berada pada usia 9 sampai 24 tahun. Namun UndangUndang Perlindungan remaja yang digunakan sebagai dasar aturan perlindungan bagi remaja mengatur bahwa remaja dikategorikan pada usia di bawah 19 tahun (kecuali ketika remaja tersebut berusia 19 tahun tepat pada 1 januari dianggap sudah bukan remaja lagi).

$$
\text { Bacaan ketiga dipilih }
$$

berdasarkan pada adanya angka dalam paragraf. Dalam bahasa Korea, angka dibaca dengan dua cara yang berbeda. Melalui paragraf ini, kemampuan pembelajar dalam membaca angka dan membedakan angka dapat diketahui.
Setelah dilakukan tes membaca teks kepada para pembelajar bahasa Korea, berdasarkan pembagian struktur kefasihan membaca oleh Pikulski \& Chard (2005), penelitian ini membaginya menjadi 4 hal; yaitu ketepatan pemahaman kosakata, tingkat kecepatan membaca, keselarasan ritme dan ekspresi, dan pemahaman isi bacaan.

\section{Ketepatan Pemahaman Kosakata}

Ketepatan pemahaman kosakata sangatlah penting dalam menilai kefasihan pembelajar bahasa asing. Pemahaman kosakata yang salah akan berdampak pada penyampaian maksud kosakata tersebut terhadap lawan bicara. Jika seseorang salah dalam memahami kosakata, maka pesan yang hendak disampaikan akan keliru atau tidak tersampaikan dengan baik.

Dalam menganalisis seberapa besar pemahaman kosakata pembelajar terhadap bacaan yang diberikan, telah ditemukan beberapa kesalahan yang terjadi dalam proses membaca kosakata dalam bacaan. 
Kesalahan pembacaan tersebut dapat dilihat sebagai berikut.

<Bacaan Pertama $>$

(1) 깻잎을 깨의 잎이라 생각하지 못하는 사람이 많다.

(2) 참깨와 들깨는 우리말 이름은 비슷하지만 분류학적으로 참깨는 꿀풀목 참깻과이므로 상당히 거리가 있다.

Dari hasil tes yang telah dilakukan pada teks bacaan pertama, telah ditemukan bahwa sebagian besar pembelajar melakukan kesalahan pada 2 kosakata dalam paragraph di atas, yaitu kosakata '깻잎[kkaenip]' dan 분류학적으로 [bullyuhakjeokeuro]. Jika dilihat pada kalimat pertama, terdapat kata 깻잎 [kkaenip] yang berasal dari 2 kata benda yang berbeda, yaitu 깨[kkae] dan 잎[ip]. 깨[kkae] memiliki arti wijen, dan 입[ip] memiliki arti daun, sehingga kedua kata tersebut jika digabung akan memiliki arti yang berbeda, yaitu daun wijen. Dalam bahasa Korea sendiri terdapat aturan penggabungan dua kata benda berbeda menjadi satu kata baru, yaitu dengan menambahkan 스 s] sebagai konsonan akhir di bawah kata benda pertama. Oleh karena itu, 깨[kkae] bergabung dengan 잎[ip], maka akan menjadi 깻입[kkaes+ip]. Secara harafiah, 깻입 dibaca dengan [kkaesip], namun kosakata tersebut tidak dapat dibaca dengan [kkaesip] tetapi harus dibaca dengan [kkaenip]. Hal ini terjadi karena ketika ada penambahan konsonan akhir 入[s] ditengah kata benda atau yang biasa disebut 사이시옷[saisiot] ini bertemu dengan vokal 이[i] di belakang, maka secara otomatis 入 $[\mathrm{s}]$ ini harus dibaca dengan ᄂ[n]. Rumitnya aturan morfologi dalam bahasa Korea sering kali membuat pembelajar merasa bingung. Sebagian besar pembelajar tidak mengerti bagaimana perubahan itu terjadi karena tidak mempelajari teori morfologi lebih dalam lagi. Banyak pembelajar bahasa Korea yang hanya mempelajari bahasa Korea melalui kursus, yang di mana dalam materi yang diajarkan kurang memadai dan bagian penting seperti perubahan 
penggunaan imbuhan $\lambda[s]$ ini sering dilupakan.

Hal ini pula yang terlihat pada hasil bacaan responden. Sebagian dari responden pembelajar, membaca kata 깻잎[kkaenip] ini dengan 깨싶[kkaesip]. Sebagian besar responden tidak tahu bagaimana cara membaca kata ini dengan benar.

Begitu pula yang terjadi pada kalimat kedua. Pada kalimat kedua terdapat kata 분류학적으로 [bullyuhakjeokeuro], sebagian besar pembelajar membacanya dengan 불류항적으로[bullyuhangjeokeuro]. Dalam kata ini, pembelajar tidak perlu merubah kata 학적[hakjeok] menjadi 항적[hangjeok]. Hal ini dikarenakan menurut aturan morfologi bahasa Korea, ketika akhiran $\neg[\mathrm{g} / \mathrm{k}]$ bertemu dengan awalan $\pi[j]$, maka secara otomatis akhiran konsonan $\neg[\mathrm{g} / \mathrm{k}]$ ini akan berubah menjadi $O$ [ng]. Namun hal ini hanya berlaku ketika akhiran tersebut masih dalam satu kosakata yang sama. Sedangkan 분류학적으로[bullyuhakjeokero] adalah gabungan dari dua kata yang berbeda, yaitu 분류학[bullyuhak] dan 적으로[jeokeuro]. Sehingga pada kosakata ini, aturan tersebut tidak berlaku. Oleh karena itu, 분류학적으로 [bulluhakjeokeuro] tetap dibaca sesuai dengan tulisannya dan tidak berubah menjadi 분류항적으로 [bullyuhangjeokeuro].

Dari keseluruhan hasil penelitian menunjukkan bahwa responden yang melakukan kesalahan baca ini adalah responden yang telah mempelajari bahasa Korea dalam kurun waktu lama, yaitu selama 4-8 tahun dan sudah memiliki nilai TOPIK level 5 dan 6. Melihat dari jangka waktu pembelajaran yang cukup lama, secara hipotesis kecil kemungkinan responden akan melakukan kesalahan dalam membaca membaca. Kesalahan membaca yang dilakukan oleh responden ini kemungkinan besar dipengaruhi oleh kurangnya materi morfologi yang diajarkan.

Sebagian besar responden mempelajari bahasa Korea di Institusi pendidikan seperti Language course, namun bukan di jurusan Bahasa Korea di jenjang universitas. Beberapa kesalahan yang terjadi terlebih terkait 
morfologi bahasa Korea merupakan hal yang sangat perlu untuk diperhatikan. Beberapa kesalahan pembelajar seperti ini dapat diakibatkan oleh materi morfologi bahasa Korea yang kurang difokuskan dalam kurikulum dan materi buku pembelajaran bahasa Korea.

$<$ Bacaan Kedua $>$

(3)유기 비료는 주로 동물의 분뇨를 발효시킨것과 풀을 썩힌것을 섞어 만든다.

(4)사람들 대부분은 유기농 채소가 일반 채소보다 더 안전하다고 생각하지만 유기비료의 원료인 동물 분뇨는 안전성에 문제가 있을 수 있다.

(5) 항생제에 노출된 동물의 분뇨에는 항생물질이 존재하는데, 이것이 건강에 좋지 않은 영향을 미치기 때문이다.

Dalam bacaan kedua, kesalahan yang terjadi bukan hanya kesalahan morfologi saja seperti dalam bacaan pertama. Dalam kalimat ke (3) terdapat kata 분뇨[bunnyo], namun beberapa responden membacanya dengan 불료[bullyo]. Hal ini dapat disebabkan oleh kurangnya pengetahuan pembaca mengenai arti kosakata tersebut sehingga ketika membaca mengalami kesalahan. Begitu pula yang terjadi pada kalimat (4), telah terjadi perubahan susunan kata ketika membaca 사람들 대부분은 [saramdeul daebubuneun]. Sebagian besar responden membacanya dengan susunan terbalik, yaitu 대부분 사람들은 [daebubun saramdeureun]. Secara makna, tidak ada pergeseran makna dalam kedua kata tersebut meskipun dibalik. Perbedaan pembelajar dalam membaca kata tersebut disebabkan dalam bahasa sehari-hari responden lebih sering mendengar kata 'daebubun saramdeureun', sehingga secara otomatis mereka membacanya demikian. Pada kalimat [5] juga terdapat kesalahan pembacaan pada kosakata 항생제에 [hangsaengje] yang seharusnya tetap dibaca demikian, namun oleh responden dibaca dengan 학생제 [haksaengje]. Hal ini dapat terjadi karena responden tidak terbiasa dengan kosakata 
'hangsaeng', namun lebih terbiasa dengan kata 'haksaeng' yang membuat responden secara otomatis membaca tulisan tersebut dengan ‘haksaeng'.

<Bacaan Ketiga>

(6) 청소년에 대한 연령 규정은 법령이나 규정에 따라 다른데, 대한민국의 청소년 기본법에는 만 9 세에서 24 세 사이(이하연령은 전부 '만 나이')의 사람으로 규정 되어 있다.

Bacaan ketiga merupakan kalimat yang di dalamnya terdapat dua jenis angka yang dibaca berbeda dalam Bahasa Korea. Namun, sebagian besar responden membaca angkaangka tersebut secara tepat. Kesalahan yang muncul pada bacaan ketiga adalah sama dengan kesalahankesalahan yang muncul pada bacaan I dan II yaitu mengenai morfologi Bahasa Korea. Dalam bacaan ketiga terdapat kosakata 연령[yeonryeong] yang seharusnya dibaca dengan 'yeollyeong' namun sebagian besar responden melakukan kesalahan pembacaan dengan membacanya sebagai 'yeonryeong'. Begitu pula pada kosakata 법령 [beobryeong] yang seharusnya dibaca dengan 'beomreyong' namun oleh responden tetap dibaca dengan 'beobryong'.

Dari hasil pembacaan yang dilakukan oleh responden, kesalahan pembacaan yang terjadi sebagian besar adalah kesalahan morfologi dalam membaca kosakata. Kesalahan morfologi dapat disebabkan oleh ketidaktahuan pembaca terhadap kosakata tersebut atau tidak terbiasa menggunakan kosakata-kosakata tersebut. Kesalahan dalam membaca kosakata-kosakata akan menyebabkan kesalahan komunikasi antara pembaca dengan pendengar. Karena dalam bahasa Korea, kesalahan pembacaan akan mengakibatkan kesalahan fatal dalam penerjemahan arti kosakata tersebut. Sebagai contoh, beberapa responden membaca 항생제 [hangsaengje] dengan 학생제 [haksaengje]. Kedua kata ini hanya memiliki perbedaan konsonan 'ng' dan ' $k$ ' namun memiliki arti yang jauh berbeda. Dalam bahasa Korea, 항생제 [hangsaengje] memiliki arti antibiotik, 
sedangkan 학생제 [haksaengje] berarti sistem pemetaan mahasiswa.

Kesalahan dalam pembacaan satu huruf saja akan menyebabkan kesalahan pemahaman arti kosakata dan kalimat yang sangat fatal. Hal ini dikarenakan perubahan satu huruf saja dalam kosakata bahasa Korea akan membuat arti kalimatnya sangat berbeda dan bahkan sulit diartikan.

\section{Tingkat Kecepatan Membaca}

Untuk mengetahui tingkat kecepatan responden dalam membaca teks dilakukan dengan cara merekam. Namun dari hasil pengamatan yang telah dilakukan, tingkat kecepatan membaca responden sangat jauh dibawah tingkat kecepatan responden dalam berbicara menggunakan bahasa Korea. Sebagian besar responden akan memperlambat kecepatan membaca mereka ketika menemui kosakata yang belum pernah didengar sebelumnya atau yang asing bagi mereka. Terlebih ketika menemui kosakata yang sulit untuk dibaca, kecepatannya akan semakin menurun bahkan sempat terhenti. Faktor yang mempengaruhi penurunan kecepatan responden dalam membaca teks dikarenakan responden lebih sering dipertemukan dengan keadaan yang memaksa mereka untuk berkomunikasi dan berbicara menggunakan Bahasa Korea, yang berbanding terbalik dengan membaca. Dalam satu hari, responden dapat berbicara menggunakan bahasa Korea dengan sangat fasih, namun untuk membaca suatu paragraf panjang akan terbata-bata. Hal ini disebabkan oleh kurangnya frekuensi praktik membaca yang dilakukan oleh responden khususnya pembelajar Bahasa Korea.

3. Keselarasan Ritme dan Ekspresi

Menyelaraskan ritme dan
ekspresi merupakan salah satu
keunggulan pembelajar Bahasa Korea
yang sudah memiliki durasi pembelajaran yang tinggi. Dengan lamanya proses pembelajaran yang sudah dialami, maka pembelajar tidak akan kesulitan untuk menyelaraskan ritme, kapan harus meninggikan dan menurunkan nada, serta bagaimana 
ekspresi dalam membaca kalimat sesuai konteksnya. Hal ini juga terjadi pada responden yang memiliki nilai TOPIK tingkat menengah atas dan telah mempelajari Bahasa Korea dalam kurun waktu lama.

Dibandingkan dengan pembelajar tingkat menengah atas, Keselarasan ritme dan ekspresi akan sulit dilihat pada pembelajar yang masih berada di tingkat pemula. Sebagian pembaca yang berada di tingkat pemula, akan lebih berfokus kepada bagaimana cara memahami kata-perkata dibandingkan dengan menyelaraskan ritme dan ekspresi ketika membaca. Oleh karena faktor tersebut, ritme dan ekspresi dalam membaca akan lebih baik jika sudah diajarkan sejak dini supaya pembelajar mulai terbiasa dengan ritme dan ekspresi penutur asli ketika membaca atau berbicara dalam bahasa Korea. Hal ini akan membuat pembelajar menjadi terbiasa dengan berbagai bentuk ritme dan ekspresi dalam membaca yang nantinya akan membantu ketika masuk ke dalam pembelajaran yang lebih tinggi.

\section{Pemahaman Isi Bacaan}

Dalam pemahaman isi bacaan, responden-responden merupakan pembelajar level menengah dan atas yang sudah terbiasa dengan strategi top-down reading atau membaca dengan memahami isi bacaan secara keseluruhan terlebih dahulu. Sehingga secara garis besar, pembelajar dapat memahami inti bacaan dan mengerti maksud serta konteks dari teks yang dibaca. Berbeda dengan pembelajar tingkat menengah dan atas, pembelajar tingkat pemula masih menggunakan strategi bottom-up reading atau membaca dengan memahami arti kata-perkata yang setelah itu disusun untuk memahami keseluruhan isi bacaan.

\section{Kesimpulan}

Melalui analisis yang dilakukan terhadap pembelajar bahasa Korea dalam konteks membaca suatu bacaan berbahasa Korea, kesimpulan yang dapat diambil adalah sebagai berikut. Kefasihan pembelajar dalam membaca suatu teks dapat dilihat melalui 4 hal, 
yaitu seberapa besar pemahaman kosakata dalam bacaan, seberapa cepat pembelajar dapat membaca teks tersebut, bagaimana pembelajar dapat mengatur ritme dan ekspresi ketika membaca, dan bagaimana pemahaman pembaca terhadap keseluruhan isi teks.

Kefasihan membaca dapat dilihat dari seberapa lama pembelajar mengalami kontak langsung dengan bahasa yang dipelajari. Namun penelitian ini membuktikan bahwa masa periode pembelajaran bukan satu-satunya faktor yang mempengaruhi tingkat kemampuan dan kefasihan dalam praktik membaca. Kefasihan membaca juga sangat dipengaruhi oleh frekuensi pembelajar dalam membaca berbagai jenis teks dalam bahasa Korea. Semakin sering pembelajar membaca teks dalam bahasa sasaran, maka tingkat kefasihan membaca pun akan meningkat. Namun yang terjadi selama ini, pembelajaran lebih difokuskan pada seberapa fasih seseorang dalam berbicara saja.
Oleh karena itu, strategi pembelajaran bahasa asing tidak hanya difokuskan pada berbicara saja, namun juga berfokus pada faktorfaktor lain seperti membaca, mendengar, dan menulis agar pembelajaran menjadi seimbang. Meskipun kefasihan seseorang ketika mempelajari bahasa asing akan lebih cepat dinilai dari bagaimana caranya berbicara, namun untuk menjadi fasih diperlukan dasar yang sangat kuat dari faktor-faktor yang lain. Semakin besar kuantitas pembelajar dalam membaca dan menggunakan berbagai macam teks, maka proses pembelajarannya akan sangat terbantu dan efektif.

\section{Daftar Pustaka}

Barr, R., Blachowicz, C., \& Wogman-Sadow, M. (2005). Reading Diagnosis for teachers: An instructional approach. White Plains, NY: Logman.

Brown, H.D. (2001). Teaching by Principles, an Interactive Approach to Language Pedagogy. New York: Addison Wesley Longman.

Carrell, P.L. (1989). Second language reading: reading ability or language proficiency. Applied Linguistics 12(2).

Eskey. David E. (1975). Advance Reading: The Structural Problem (In the Art of Tesole) 
Gardner, D. (2004). Vocabulary input through extensive reading: A comparison of words found in children's narrative and expository reading materials. Applied Linguistics, 25(1).

Jensen, L. (1986). Advanced reading skills in a comprehensive course. In $F$. Dubin, D. E. Eskey, \& W. Grabe (Eds.). Teaching second language reading for academic purposes. MA: Addison Wesley.

Khun, R. Melanie \& Levy, Lorell. (2015). Developing Fluent Readers: Teaching Fluency as a Foundational Skill. New York: The Guilford Press.

LaBerge, D., \& Samuels, S. (1974). Toward a theory of automatic information processing in reading. Cognitive Psychology, 6, 293-323.

Heibert, E. H., \& Fisher, C. W. (2002). The critical word factor in the text for beginning readers: Effects on reading speed, accuracy, and comprehension. Paper presented at the annual meeting of American Educational Research Association, April 4, 2002.

Pikulski, J. J., \& Chard, D. J. (2005). Fluency: Bridge between decoding and reading comprehension. The Reading Teacher, 58, 510-519.

Walker, B. J., Mokthari, K., \& Sargent, S. (2006). Reading fluency more that fast and accurate reading. In Rasinski, T. V., \& Blachowics, C. (Eds), Fluency
Instruction research-based best practices (pp.86-105), New York: The Guilford Press.

강현화.김민옥. 김제열.우인혜. 이숙 (2009).「한국어 이해교육론」, 형설 출판사.

김다혜(2007). 「학문 목적 한국어학습자의 읽기 능력 향상을 위한 마인드맵 활용연구」, 이화여대교육 대학원석사.

김소현(2002).「과업유형에 따른 영어 읽기 능력 향상 효과에 대한연구」, 이화여대대학원 석사학위논문.

김현연(2005). 「텍스트 구조 지도가 읽기에 미치는 영향 연구」, 『국어교육연구』 37.

김애화,박성희,김주현(2010).

「초등학생의 읽기 유창성 특성연구: 읽기유창성 발달패턴 및 오류유형 분석」, 한국어 청각임상학회.

노순관(1985). 「읽기학습기능의

지도방안」, 『교육연구』190,

한국교육 생산성연구소.

손경숙(2000). 「한국어학습자의 읽기 전략훈련과 학습결과 분석연구 $\lrcorner$, 연세대학교 교육대학원 석사학위논문.

하원영(2012). 「초등학생의 영어 읽기 유창성 발달에서 반복읽기와 확대읽기의 효과비교」, 한국외국어대학교 석사학위논문.

\section{Lampiran}




\section{한국어학습자읽기능력유창성실험연구를위한설문지}

\section{Kuisioner Kefasihan Pembelajar Bahasa Korea dalam Membaca Teks Berbahasa Korea}

안녕하세요?

여러분의 소중한 시간을 내주셔서 감사드립니다.

본 설문지는 외국인 한국어 학습자의 읽기 능력 유창성 실험 연구를 위한 것이며 학습자 읽기 능력 유창성 문제 요인을 파악하기 위한 설문조사 입니다. 본 설문은 연구 기초 자료로만 활용될 것이며 기타의 다른 어떤 용도로도 사용되지 않으므로 각 해당되는 질문에 귀하 여러분께서 진솔하게 대답해주시면 고맙겠습니다.

렌찌딥티아

\section{Selamat Pagi/Siang/Sore?}

Terimakasih telah meluangkan waktu anda untuk mengisi kuisioner ini.

Kuisioner ini akan digunakan untuk penelitian terkait dengan menganalisa kefasihan membaca pembelajar Bahasa Korea dan merupakan salah satu bahan untuk menganalisa faktor-faktor penyebab terjadinya kesalahan dalam praktik membaca. Kuisioner ini hanya akandijadikan sebagai bahan dasar penelitian, dan tidak dipergunakan untuk hal-hal di luar penelitian. Dengan demikian kami mohon kerjasamanya dalam pengisian kuisioner berikut ini.

Terimakasih atas kerjasamanya.

Th A Rencidiptya G F

1. 성별(jenis kelamin):

2. 연령(usia): 세(tahun)

3. 국적(kewarganegaraan):

4. 직업(pekerjaan):

5. 현재 거주지(tempat tinggal):

6. 현재까지 한국어를 배운지 얼마나 되었습니까?

(Berapa lama mempelajari Bahasa Korea sampai saat ini?)
(a) 년이하 (di bawah 1 tahun)
(b) 년 4 년 (1-4 tahun)
C94 년 8 년 (4-8 tahun)
(d8 년이상 (di atas 8 tahun)

7. 한국어를 어떻게 배웠습니까? (1 개이상선택가능) 
(Bagaimana awal mempelajari Bahasa Korea? (dapat dijawab lebih dari satu)
(3)자서(otodidak)
어학당 (kelas bahasa di universitas)
(d)학교전공(jurusan)
(e)ㅣㅣ강(pekerjaan)

(b)학원(khursus)

8. 한국어를 어디에서 배웠습니까?

(Dimana mempelajari Bahasa Korea?)

(a)국에서만 (di negara asal) (b한국에서만 (di Korea)

C모국에서 및 한국에서 (di negara asal dan di Korea)

9. 요즘 한국어와 얼마나 자주 부딪치십니까?

(Seberapa sering menggunakan Bahasa Korea?)

항상 (하루에 8 시간이상) Selalu (lebih dari 8 jam sehari)

(b)주주 (하루에 3 7 시간) Sering (3-7 jam sehari)

아끔 (하루에 2 시간이하) Kadang-kadang (di bawah 2 jam sehari)

(d부딪칠일없다 (tidak pernah)

10. 귀하의 모국어를 비하여 한국어를 어떻게 생각하십니까?

(Bagaimana tingkat kesulitan mempelajari Bahasa Korea dibandingkan dengan bahasa ibu?)

(a)우쉽다(sangat mudah)

(b웝다 (mudah)

땅간 (쉽지도않고 어렵지도않다) sedang, tidak mudah tidak sulit)

@어렵다(sulit)

(e)매우어렵다 (sangat sulit)

11. 귀하의 모국어를 비해 한국어는 어떤 부분이 제일 어렵다고 생각하십니까?

(Dibandingkan dengan bahasa ibu, bagian mana dari Bahasa Korea yang dirasa sulit?)

(2국장어순 (susunan kalimat) (b웁ㅂㅂㅂ (tata bahasa) 

안어, 어휘(kosakata)
(d)ㅏㄹㄹ음(pelafalan)
(e)| EF lain-lain ( )

12. 한국어 학습 유형 중에 제일 쉬운 것부터 제일 어려운 것까지 $1,2,3,4$ 번호로 표시해 주십시오.

(Urutkan materi dalam Bahasa Korea dari yang termudah hingga yang tersulit dengan urutan 1,2,3,4)

(a) 기 menyimak

(b)ㅏㅏㄹ하기 berbicara

직기 membaca

(d) 기 menulis

13. 귀하께서는 현재 토픽 급을 가지고 있으십니까? 토픽 급을 쓰십시오.

(Apakah anda memiliki nilai TOPIK? Jika ada tuliskan.
(a)네 Ya. ( 급 Level)
(b) 아니요 Tidak.

14. 시간을 드릴테니 마음속으로 다음 문장을 읽고난 후 소리내어 읽으십시오. Bacalah teks di bawah ini dengan suara yang lantang.

(녹음해서 보내주시기 바랍니다) Kirimkan hasil rekaman teks berikut.

a. 깻잎을 깨의 잎이라 생각하지 못하는 사람이 많다. 참깨와 들깨는 우리 말 이름은 비슷하지만 분류학적으로 참깨는 꿀풀 목 참깻과이므로 상당히 거리가 있다.

b. 일반적으로 채소를 기를때는 영양공급을 위해 비료를 주는데, 일반 채소의 경우 화학비료를 쓴다. 그러나 일반 채소보다 값비싼 유기농 채소에는 유기비료를 사용한다. 유기비료는 주로 동물의 분뇨를 발효시킨것과 풀을 썩힌 것을 섞어 만든다. 사람들 대부분은 유기농 채소가 일반채소보다 더 안전하다고 생각하지만 유기비료의 원료인 동물 분뇨는 안전성에 문제가 있을 수 있다. 항생제에 노출된 동물의 분뇨에는 항생물질이 존재하는데, 이것이 건강에 좋지 않은 영향을 미치기 때문이다. 또한 분뇨에 많이 들어있는 질소 
성분이 고기나 생선에 포함되어 있는 단백질과 결합하면 암 발생물질을 생성할 수 있다.

c. 하면 만 13 세 이상만 18 세이하 (세는 나이로 14 세 이상 19 세 이하)사람을 말하며, 통상 중학교와 고등학교의 시기에 해당된다. 청소년에 대한 연령 규정은 법령이나 규정에 따라 다른데, 대한민국의 청소년 기본법에는 만 9 세에서 24 세 사이(이하연령은 전부 '만 나이’)의 사람으로 규정되어 있다. 그러나 청소년의 보호와 규제를 목적으로 하는 청소년 보호법에서는 19 세 미만(19 세가 되는 해의 1 월 1 일을 맞이한 사람은 제외한다)을청소년으로 정의하고 있다.

시간을내어주셔서감사합니다

Terimakasih atas kerjasamanya 